\title{
PENGARUH PENGAJARAN REMEDIAL MENGGUNAKAN STRATEGI ANALOGI TERHADAP MISKONSEPSI IPA
}

\author{
Nur Hikmah Fitratin ${ }^{1}$, Dyah Ayu Fajarianingtyas ${ }^{2}$, Henny Diana Wati ${ }^{3}$ \\ Universitas Wiraraja ${ }^{1,2,3}$ \\ nfitratin@gmail.com ${ }^{1}$, tanzilkurnain@gmail.com ${ }^{2}$
}

\begin{abstract}
ABSTRAK
Penelitian ini bertujuan untuk mengetahui 1) Keterlaksanaan pengajaran remedial menggunakan strategi analogi terhadap siswa kelas VII SMP Negeri 1 Saronggi, 2) Perbedaan miskonsepsi IPA antara pengajaran remedial menggunakan strategi analogi dan pengajaran remedial menggunakan strategi pembelajaran langsung, 3)Peningkatan hasil belajar siswa kelas VII setelah menggunakan pengajaran remedial menggunakan strategi analogi. Jenis penelitian ini adalah penelitian kuantitatif menggunakan quasi experimental design. Teknik pengambilan sampel menggunakan teknik cluster random sample. Teknik pengumpulan data menggunakan instrumen tes dengan metode CRI dan non tes. Data yang di analisis menggunakan uji Mann-Whitney. Hasil penelitian menunjukkan 1) Keterlaksanaan pengajaran remedial menggunakan strategi analogi sebesar $98 \%$ dengan kategori sangat baik dan keterlaksanaan pengajaran remedial menggunakan strategi pembelajaran langsung sebesar 91\% dengan kategori sangat baik. 2) Hasil uji MannWhitney sebesar 0,017 yang menunjukkan bahwa terdapat perbedaan miskonsepsi IPA antara pengajaran remedial menggunakan strategi analogi dengan pengajaran remedial menggunakan strategi pembelajaran langsung. 3) Hasil gain score pada kelas eksperimen sebesar 0,71 dengan kategori tinggi, sedangkan pada kelas kontrol sebesar 0,52 dengan kategori sedang. Pengajaran remedial menggunakan strategi analogi dapat digunakan untuk mengatasi miskonsepsi pada siswa.
\end{abstract}

Kata Kunci: Pengajaran Remedial, Strategi Analogi, Miskonsepsi IPA

\begin{abstract}
This research aims to find out 1) Remedial teaching implementation using analogy strategy to VII grade students of SMP Negeri 1 Saronggi, 2) Differences of IP science misconception between remedial teaching using analogy strategy and remedial teaching using direct learning strategy, 3) Improvement of student learning outcomes of grade VII after using remedial teaching using analogy strategies. This type of research is quantitative research using quasi experimental design. The sampling technique used cluster random sample technique. Technique of collecting data using test instrument with CRI and non test method. The data were analyzed using MannWhitney test. The results showed 1) The implementation of remedial teaching using analogy strategy of $98 \%$ with very good category and the implementation of remedial teaching using direct learning strategy of $91 \%$ with very good category. 2) Mann-Whitney test result of 0,017 indicating that there is difference of science misconception between remedial teaching using strategy analogies with remedial teaching using direct learning strategy. 3) The result of gain score in the experimental class is 0,71 with the high category, while the control class is 0,52 with the medium category. Remedial teaching using analogy strategies can be used to address misconceptions in students.
\end{abstract}

Keywords: Remedial Teaching, Strategy Analogy, Misconception of Natural Science

\section{PENDAHULUAN}

Secara keseluruhan dalam proses pengajaran, hakikatnya guru memiliki tanggung jawab ataupun peran yang luas sebagai tenaga pengajar untuk membantu siswa mencapai tujuan yang diharapkan, 
sehingga akan mencapai hasil belajar yang optimal. Tujuan tersebut dapat tercapai jika setiap kesulitan yang timbul dalam belajar segera diidentifikasi dan dilakukan perbaikan, sehingga guru perlu memahami dan menguasai kemampuan melakukan pengajaran remedial. Pengajaran remedial juga disebut dengan kegiatan perbaikan karena dilakukan dalam upaya mendiagnosa jenis dan sifat masalah yang dihadapi siswa dalam belajar, kemudian mencari penyebab dan solusinya. Solusi masalah kesulitan belajar tersebut dapat berupa pencegahan atau penyembuhan, bergantung pada jenis dan sifatnya (Kunandar, 2014). Kesulitan belajar menjadi masalah yang hampir seluruh siswa alami. Setiap siswa mengalami jenis kesulitan belajar yang berbeda, karena perbedaan dalam memahami materi (Subini, 2015). Kesulitan belajar dapat menyebabkan kesalahan pemahaman konsep tertentu dan kesalahan dalam memahami konsep secara berlanjut dapat berandil besar dalam miskonsepsi. Miskonsepsi yang ada pada diri siswa juga dapat menyebabkan timbulnya kesulitan untuk memahami konsep berikutnya (Suwarto, 2013).

Miskonsepsi adalah pemahaman konsep yang keliru dan tidak sesuai dengan konsep ilmuan tertentu. Konsep yang siswa miliki secara umum dibentuk oleh akal sehat dan dibentuk secara intuitif untuk memberi makna pada pengalaman hidup mereka (Suwarto, 2013). Miskonsepsi muncul jika hasil kontruksi pengetahuan siswa tidak cocok dengan hasil kontruksi pengetahuan para ilmuwan. Informasi baru (dalam persepsi konstruktivis) masuk ke skemata melalui 2 proses, yaitu asimilasi dan akomodasi. Individu menerima informasi yang baru dengan memanfaatkan kemampuan dan informasi yang sudah terbentuk sebelumnya untuk beradapatasi pada proses asimilasi. Proses asimilasi menunjukkan proses perolehan informasi baru yang sesuai dengan informasi yang sudah dimiliki. Proses akomodasi menunjukkan cara yang berbeda, yakni penerimaan informasi baru yang dilakukan dengan memodifikasi informasi yang sudah terbentuk sebelumnya. Struktur kognitif yang sudah ada dengan informasi yang baru didapat harus sesuai, agar struktur kognitif seimbang. Penyusunan kembali struktur kognitif perlu dilakukan jika struktur kognitif yang sudah ada tidak sesuai dengan informasi baru (Setiawati, Arjaya and Ekayanti, 2014). Miskonsepsi yang tidak menjadi perhatian dalam pembelajaran menyebabkan kesulitan belajar, sehingga hasil belajar siswa akan rendah (Praswidiarini and Suyono, 2015).

Berdasarkan hasil penelitian menunjukkan sebagian siswa mengalami miskonsepsi yang dibuktikan dengan observasi awal yaitu hasil angket dan wawancara. Hal ini disebabkan materi tersebut bersifat abstrak, sifat konsep yang abstrak sulit untuk divisualisasikan, sehingga membuat siswa kesulitan dalam menelaah konsep tersebut. Menurut Fathurohman (2014) Permasalahan sifat konsep yang abstrak dapat diatasi dengan menggunakan model pembelajaran, atau media sebagai model. Media yang digunakan salah satu guru IPA SMPN 1 Saronggi hanya berupa media gambar yang tertera di buku ajar. Hal ini menyebabkan siswa masih merasa kesulitan dalam menerima pelajaran karena ada beberapa materi yang tidak cukup hanya dijelaskan melalui gambar. Kehadiran analogi mutlak diperlukan khususnya jika materi ajar sulit dijangkau oleh panca indera, karena dengan analogi siswa dapat membandingkan materi ajar dengan konsep yang dikenal siswa dalam kehidupan, sehingga siswa dapat memahami dengan mudah, terutama untuk konsep-konsep abstrak (Prastowo, 2011). Upaya yang dilakukan oleh salah satu guru IPA untuk mengatasi masalah tersebut yaitu dengan cara mengadakan remedial. Pengajaran remedial yang dialakukan di sekolah tersebut seharusnya menjadi solusi bagi masalah kesulitan 
belajar. Faktanya pengertian tersebut belum sejalan dengan pelaksanaan di SMPN 1 Saronggi, karena berdasarkan wawancara pada guru IPA dan siswa kelas VII mengatakan bahwa remedial yang diadakan disekolah tersebut dilaksanakan dengan cara pemberian tugas tanpa ada bimbingan khusus atau pembelajaran ulang pada peserta didik. Menurut Sari, Prasetyo and Utami (2014) dalam penelitiannya mengungkapkan bahwa pembelajaran remidial, sebaiknya dilakukan dengan cara memberikan pembelajaran ulang sebelum dilakukan tes ulang dibandingkan pemberian tugas untuk dikerjakan di rumah, karena guru dapat memantau aktivitas siswa selama pembelajaran berlangsung untuk menilai perkembangan pengetahuan siswa mengenai materi yang diremidialkan. Proses pengajaran remedial memiliki sifat khusus, karena pengajaran dilakukan sesuai dengan jenis dan sifat kesulitan belajar siswa, pada pengajaran remedial, guru bisa menggunakan pendekatan yang disesuaikan dengan keanekaragaman tingkat kemampuan pribadi siswa dan siswa mendapatkan kesempatan belajar sesuai kemampuannya masing-masing (Basri, 2011). Pelaksanaan remedial bisa tepat sasaran apabila dilengkapi dengan strategi. Strategi analogi dapat digunakan dalam rangka meprevensi miskonsepsi siswa, sehingga penelitian tersebut menjadi dasar untuk melakukan penelitian "Pengaruh pengajaran remedial menggunakan strategi analogi terhadap miskonsepsi IPA pada siswa kelas VII SMP Negeri 1 Saronggi" Penelitian ini bertujuan untuk mengetahui keterlaksanaan pengajaran remedial menggunakan strategi analogi terhadap siswa kelas VII SMP Negeri 1 Saronggi, untuk mengetahui perbedaan miskonsepsi IPA antara pengajaran remedial menggunakan strategi analogi dan pengajaran remedial menggunakan strategi pembelajaran langsung dan untuk mengetahui peningkatan hasil belajar siswa kelas VII setelah menggunakan pengajaran remedial menggunakan starategi analogi.

\section{METODE PENELITIAN}

Jenis penelitian ini adalah penelitian kuantitatif. Rancangan penelitian ini menggunakan Quasi Eksperimental Design. Teknik pengambilan sampel pada penelitian ini menggunakan teknik cluster random sample yang mengacu pada kelompok. Sampel dalam penelitian ini adalah siswa kelas VII C dan VII D dengan jumlah 23 dan 23 siswa, jadi jumlah keseluruhan adalah 46 siswa.

Instrumen yang digunakan untuk memperoleh data pada penelitian ini adalah instrumen tes dan non tes. Instrumen tes digunakan untuk mengetahui miskonsepsi IPA pada siswa dengan menggunakan metode CRI, sedangkan Instrumen non tes digunakan untuk mengetahui keterlaksanaan pengajaran remedial menggunakan strategi analogi terhadap miskonsepsi IPA pada siswa. Analisis data yang digunakan untuk mengetahui miskonsepsi yaitu berdasarkan hasil tes yang diberikan menggunakan skala CRI, sedangkan analisis data untuk menguji beda miskonsepsi yaitu menggunakan uji Mann Whithney untuk mengetahui peningkatan hasil belajar siswa kelas VII setelah menggunakan pengajaran remedial menggunakan starategi analogi

\section{HASIL PENELITIAN}

\section{Keterlaksanaan Pembelajaran}

Pengajaran remedial dilaksanakan tanggal 26-27 April 2017 pada kelas VIIC sebagai kelas eksperimen yaitu menggunakan strategi analogi dan kelas VII-D sebagai kelas kontrol yaitu menggunakan strategi pembelajaran langsung. Hasil yang diperoleh berdasarkan keterlaksanaan pembelajaran yang diamati oleh dua pengamat dapat dilihat pada Tabel 1. 
Tabel 1. Tabulasi

Keterlaksanaan Pembelajaran

\begin{tabular}{cc}
\hline Kelas & Rata-Rata (\%) \\
\hline Kontrol & 91 \\
\hline Eksperimen & 98 \\
\hline
\end{tabular}

Berdasarkan tabel 1 menunjukkan bahwa persentase keterlaksanaan pembelajaran pada kelas kontrol sebesar 91\% dengan kategori sangat baik, sedangkan persentase keterlaksanaan pembelajaran pada kelas eksperimen sebesar $98 \%$ dengan kategori sangat baik. Adapun data hasil keterlaksanaan pembelajaran antara setiap tahap pada kelas kontrol dan kelas eksperimen dapat dilihat pada Gambar 1.

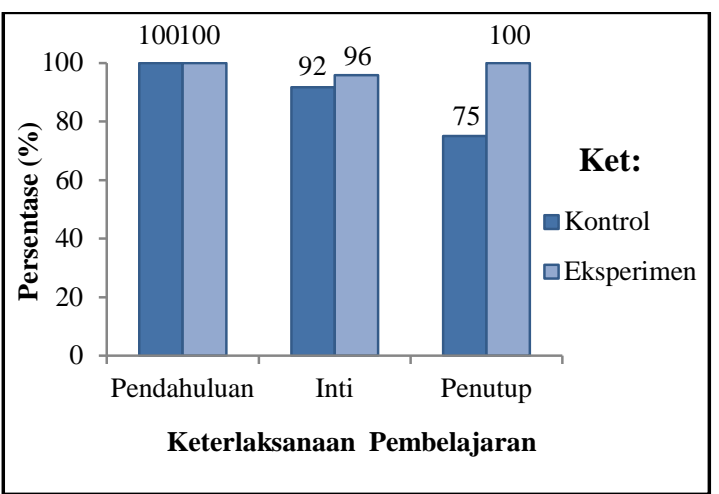

Gambar 1. Nilai Keterlaksanaan

Pembelajaran Kelas Kontrol dan Kelas Eksperimen
Berdasarkan gambar 1 persentase keterlaksanaan pembelajaran pada tahap pendahuluan memperoleh hasil yang sama antara kelas kontrol dan kelas eksperimen yaitu sebesar 100\%. Pada tahap inti persentase keterlaksanaan pembelajaran memiliki sedikit mengalami perbedaan yaitu pada kelas kontrol memperoleh hasil $92 \%$ dan kelas eksperimen 96\% dikarenakan nilai yang diberikan kedua pengamat berbeda. Sedangkan pada tahap penutup persentase kedua kelas tidak sama yaitu nilai kelas kontrol lebih kecil dari pada kelas eksperimen.

2. Perbedaan Miskonsepsi IPA Antara Pengajaran Remedial Menggunakan Strategi Analogi dengan Pengajaran Remedial menggunakan Strategi Pembelajaran Langsung

Berdasarkan hasil tes menggunakan skala CRI dapat diketahui siswa yang mengalami miskonsepsi, tidak tahu konsep dan tahu konsep. Adapun perbandingan rata-rata persentase dari ketiga kategori dapat dilihat pada Gambar 2.

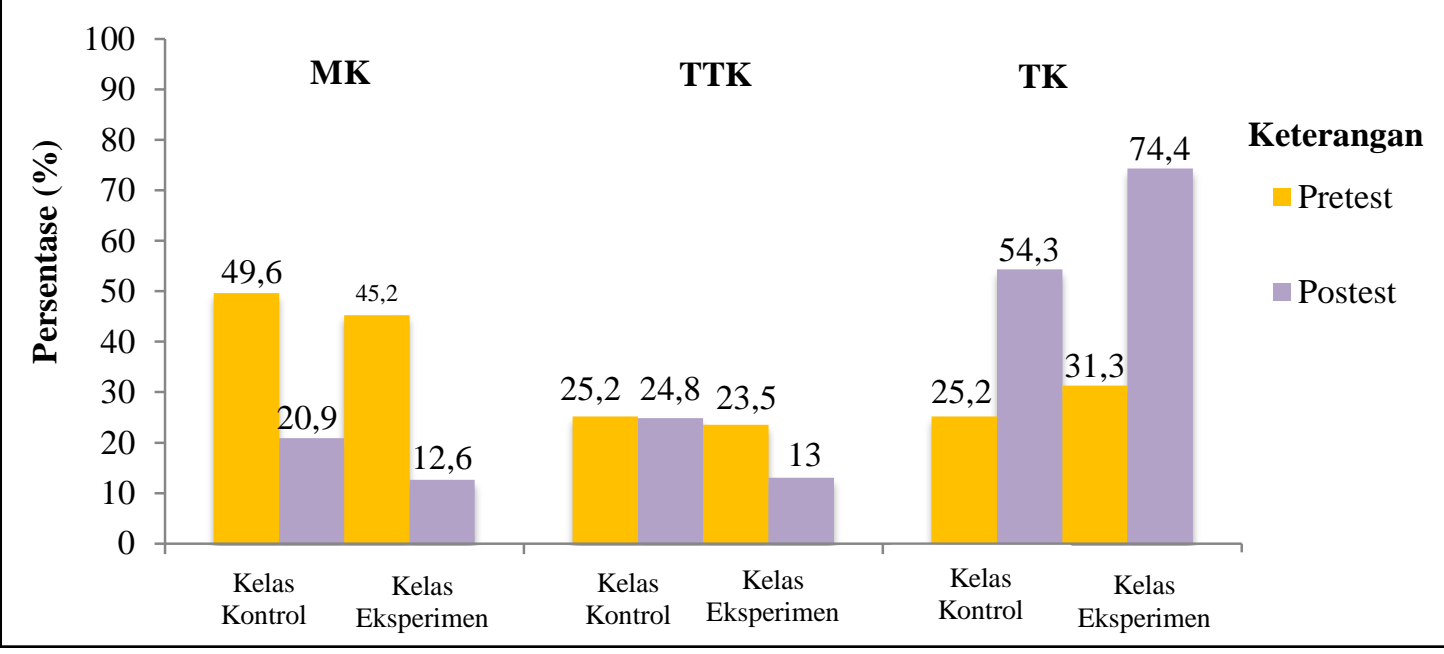

Gambar 2. Perbandingan Rata-Rata Persentase Miskonsepsi (MK), Tidak Tahu Konsep (TTK), dan Tahu Konsep (TK) antara Kelas Kontrol dan Kelas Eksperimen 
Berdasarkan gambar 2 menunjukkan bahwa saat pretest jumlah siswa yang mengalami miskonsepsi sangat menonjol dibandingkan dengan yang tahu konsep dan tidak tahu konsep pada kelas kontrol maupun kelas eksperimen. Sedangkan pada saat posttest jumlah siswa yang tahu konsep lebih menonjol dibandingkan dengan yang miskonsepsi dan tidak tahu konsep. Hal ini, membuktikan bahwa setelah perlakuan remedial siswa banyak memahami konsep terutama pada kelas eksperimen yang mengalami kenaikan lebih besar dari pada kelas kontrol.

\section{Peningkatan Hasil Belajar setelah Pengajaran Remedial menggunakan Strategi Analogi}

Hasil nilai pretest dan posttest yang telah diperoleh terlebih dahulu dihitung melalui gain score sehingga dapat diketahui peningkatan hasil belajar setelah dilakukan pengajaran remedial menggunakan strategi analogi dan strategi pembelajaran langsung. Nilai gain score dapat dilihat pada Tabel 2 .

Tabel 2. Perbandingan Hasil Nilai RataRata Gain Score

\begin{tabular}{cccc}
\hline \multicolumn{4}{c}{ Hasil Nilai Rata-Rata Gain Score } \\
\hline $\begin{array}{c}\text { Kelas } \\
\text { Kontrol }\end{array}$ & Kategori & $\begin{array}{c}\text { Kelas } \\
\text { Eksperimen }\end{array}$ & Kategori \\
\hline 0,52 & Sedang & 0,71 & Tinggi \\
\hline
\end{tabular}

\footnotetext{
Berdasarkan tabel 2 menujukkan bahwa selain terjadi penurunan miskonsepsi, juga terjadi peningkatan hasil belajar pada kelas kontrol maupun kelas eksperimen. Data peningkatan hasil belajar setelah pengajaran remedial menggunakan strategi analogi diperoleh dari nilai gain score.

Pengujian hipotesis dalam penelitian ini bertujuan untuk mengetahui adakah perbedaan pengajaran remedial menggunakan strategi analogi dengan strategi pembelajaran langsung terhadap
}

miskonsepsi IPA. Hasil pengujian hipotesis ini ialah sebagai berikut:

a. Uji Normalitas

Berdasarkan uji normalitas diperoleh nilai signifikansi kelas kontrol sebesar 0,000 dan kelas eksperimen sebesar 0,008 dari nilai signifikansi tersebut dapat dinyatakan bahwa kelas eksperimen dan kelas kontrol tidak berdistribusi normal, sehingga dilanjutkan pada uji MannWhitney.

b. Uji Beda

Berdasarkan hasil uji MannWhitney menunjukkan bahwa: Terdapat perbedaan miskonsepsi IPA antara pengajaran remedial menggunakan strategi analogi dengan pengajaran remedial menggunakan strategi pembelajaran langsung dengan nilai signifikansi (2-tailed) 0,017 atau kurang dari 0,05 yang berarti bahwa tolak $H_{0}$ dan terima $H_{1}$. Output uji Mann-Whitney

\section{PEMBAHASAN}

\section{Keterlaksanaan Pembelajaran}

Berdasarkan hasil penelitian menunjukkan bahwa persentase keterlaksanaan pembelajaran pada kelas kontrol sebesar 91\% dengan kategori sangat baik, sedangkan persentase keterlaksanaan pembelajaran pada kelas eksperimen sebesar 98\% dengan kategori sangat baik. Hal ini menunjukkan bahwa sintak atau langkah-langkah pembelajaran pada kedua kelas sesuai dengan yang telah direncanakan dalam RPP.

Tahap keterlaksanaan pembelajaran pada kelas eksperimen dalam penelitian ini yaitu: Mengenalkan konsep target. Konsep target merupakan konsep yang tidak umum atau tidak diketahui dengan baik dan akan diajarkan kepada siswa. Konsep target dalam penelitian ini yaitu struktur bumi pada konsep lapisan penyusun bumi dan pergerakan lempeng dapat dilihat pada Tabel 3 . 
Tabel 3. Penjelasan Konsep Target

\begin{tabular}{cll}
\hline \multirow{2}{*}{ Konsep } & $\begin{array}{l}\text { Lapisan } \\
\text { Penyusun } \\
\text { Bumi }\end{array}$ & $\begin{array}{l}\text { Lapisan penyusun bumi terdiri dari: kerak bumi yang berbentuk padat } \\
\text { bebatuan, mantel bumi yang berbentuk cair-padat (liquid), inti luar yang } \\
\text { berbentuk cair dan inti dalam yang berbentuk padat. }\end{array}$ \\
\cline { 2 - 3 } $\begin{array}{l}\text { Pergerakan } \\
\text { Lempeng }\end{array}$ & $\begin{array}{l}\text { Benua-benua bergerak relatif terhadap satu sama lainnya yang diakibatkan } \\
\text { oleh arus konveksi yang terjadi di mantel bumi }\end{array}$ \\
\hline \multirow{2}{*}{ Siswa } & $\begin{array}{l}\text { Lapisan } \\
\text { Penyusun } \\
\text { Bumi }\end{array}$ & $\begin{array}{l}\text { Siswa sering kali mengalami kesulitan untuk membayangkan bentuk lapisan } \\
\text { penyusun bumi }\end{array}$ \\
\cline { 2 - 3 } & $\begin{array}{l}\text { Pergerakan } \\
\text { Lempeng }\end{array}$ & $\begin{array}{l}\text { Siswa sering tidak menyadari mekanisme yang mendorong pergerakan benua, } \\
\text { atau mereka memiliki pemahaman keliru yang berkaitan dengan rotasi bumi } \\
\text { atau pendinginan global atau mereka percaya bahwa lempeng-lempeng bumi } \\
\text { berputar mengelilingi pusatnya. }\end{array}$ \\
\hline
\end{tabular}

Selanjutnya yaitu menunjukkan konsep analog. Konsep analog adalah konsep yang umum atau diketahui dengan baik dan biasanya telah lebih dahulu diajarkan kepada para siswa (Fathurohman, 2014). Konsep analog dalam penelitian ini dapat dilihat pada Tabel 4.

Tabel 4. Penjelasan Konsep Analogi

\begin{tabular}{lll}
\hline \multirow{2}{*}{ Analog } & $\begin{array}{l}\text { Lapisan } \\
\text { Penyusun } \\
\text { Bumi }\end{array}$ & Buah Kiwi (Actinidia deliciosa) \\
\cline { 2 - 3 } & & $\begin{array}{l}\text { Sebuah model terdiri dari gelas kimia berisi air yang dicampur dengan } \\
\text { pewarna makanan dan kertas HVS yang menggambarkan benua diatas }\end{array}$ \\
Pergerakan & $\begin{array}{l}\text { permuakaan air. Sumber panas menggunakan pembakar spirtus menghasilkan } \\
\text { arus konveksi yang dapat dilihat siswa. Model ini menunjukkan bagaimana } \\
\text { arus konveksi didalam mantel bumi bisa menyebabkan pergerakan lempeng } \\
\text { menjadi terpisah didalam pergeseran benua }\end{array}$ \\
\hline
\end{tabular}

Setelah menunjukkan konsep analog yaitu mengidentifikasi persamaan di antara komponen konsep analog dan konsep target. Mengumpulkan seluruh fitur atau atribut baik dari konsep target dan konsep analog untuk didentifikasi.

Langkah selanjutnya memetakan kesesuaian/keserupaan antara konsep analog dan konsep target. Jika terdapat banyak fitur/ atribut serupa, sebuah analogi dapat ditarik atau diambil, semakin banyak fitur/atribut serupa berarti analoginya semakin baik (Fathurohman, 2014). Kemiripan kedua konsep dalam penelitian ini dapat dilihat pada Tabel 5.

Tabel 5. Kemiripan Konsep Analog dan Target

\begin{tabular}{|c|c|}
\hline \multicolumn{2}{|c|}{ Kemiripan - Pemetaan Analog dengan Target } \\
\hline Analog - Buah Kiwi (Actinidia deliciosa) & Target - Lapisan Penyusun Bumi \\
\hline a. Kulit berwarna kecoklatan & a. Kerak Bumi \\
\hline b. Daging berwarna hijau kusam & b. Mantel Bumi \\
\hline c. Daging berwarna hijau terang & c. Inti Luar \\
\hline d. Biji & d. Inti dalam \\
\hline Analog - Arus konveksi didalam Air & Target \\
\hline $\begin{array}{l}\text { Cairan berwarna bergerak ke atas dari daerah } \\
\text { pemanasan }\end{array}$ & a. Magma mengalir keatas melewati kerak \\
\hline b. Pembakar spirtus sebagai sumber panas & $\begin{array}{l}\text { b. Reaksi Radioaktif yang diakibatkan arus } \\
\text { konveksi }\end{array}$ \\
\hline $\begin{array}{l}\text { Kertas bergerak saling mnjauhi/ saling mendekat } \\
\text { diatas permukaan air }\end{array}$ & $\begin{array}{l}\text { c. Gerakan kerak bumi yang diakibatkan arus } \\
\text { konveksi }\end{array}$ \\
\hline $\begin{array}{l}\text { Cairan berwarna turun ditepian wadah karena } \\
\text { mengalami pendinginan }\end{array}$ & $\begin{array}{l}\text { d. Magma masuk kebawah ditepian lempeng } \\
\text { tektonik }\end{array}$ \\
\hline
\end{tabular}


Langkah terakhir yaitu menyatakan bagian-bagian yang beranalogi dan menarik kesimpulan. Fitur atau atribut yang tidak serupa merupakan pengecualian dari analogi tersebut (Fathurohman, 2014). Ketidaksesuaian kedua konsep dalam penelitian ini dapat dilihat pada Tabel 6 .

Tabel 6. Ketidakmiripan Konsep Analog dan Target - Dimana Letak Kelemahan Analogi

\begin{tabular}{ll}
\hline Model Lapisan Penyusun Bumi & Model Pergerakan Lempeng \\
\hline Model ini tidak dapat menggambarkan suhu & Kecepatan model ini beroperasi sama sekali tidak \\
pada lapisan-lapisan penyusun bumi & memiliki hubungan dengan kecepatan nyata. Selain itu \\
& Tidak ada penggambaran pelipatan kerak bumi \\
\hline
\end{tabular}

2. Perbedaan Miskonsepsi IPA antara Pengajaran Remedial menggunakan Strategi Analogi dengan Pengajaran Remedial menggunakan Strategi Pembelajaran Langsung

Berdasarkan hasil penelitian, miskonsepsi yang terjadi pada kelas eksperimen lebih rendah 8,36\% dibandingkan miskonsepsi yang terjadi pada kelas kontrol. Hal ini dikarenakan strategi analogi memberikan citra visual (bayangan) yang kuat melalui konsep yang sudah dikenal sebelumnya atau keadaaan nyata sehingga dapat dengan mudah dihubungkan dengan konsep abstrak seperti buah kiwi yang dianalogikan sebagai konsep lapisan penyusun bumi. Sedangkan strategi pembelajaran langsung memberikan keterampilan tahap demi tahap dengan menggunakan contoh seperti gambar sehingga juga dapat menjembatani antara konsep yang belum dikenal dengan konsep abstrak. Hasil penelitian menunjukkan bahwa pengajaran remedial yang menggunakan strategi analogi mengalami penurunan miskonsepsi sebesar $32,17 \%$, sedangkan pengajaran remedial yang menggunakan strategi pembelajaran langsung juga mengalami penurunan sebesar 28,69\%. Hal ini sesuai dengan penelitian yang dilakukan oleh Praswidiarini and Suyono (2015) menyatakan bahwa strategi analogi efektif mencegah potensi miskonsepsi siswa dibuktikan dengan status miskonsepsi siswa lebih rendah dari penelitian terdahulu.
Penurunan rata-rata persentase miskonsepsi tersebut juga disebabkan siswa telah memahami konsep melalui pengajaran remedial yang dibuktikan dengan siswa menjawab soal benar (skala CRI tinggi). Hasil tersebut dikarenakan pelaksanaan remedial telah disesuaikan dengan jenis dan sifat kesulitan yang dihadapi. Jenis kesulitan pada penelitian ini yaitu kesulitan siswa memahami konsep dalam bentuk narasi untuk membaca peristiwa yang abstrak, sehingga menyebabkan siswa mengalami miskonsepsi. Adapun sifat kesulitan dalam penelitian ini yaitu sulit untuk diperbaiki. Sesuai dengan pernyataan Nussbaus (Harrison, 2013) bahwa "apabila siswa pernah mempelajari konsep yang keliru, maka konsep pemikiran mereka akan sulit untuk di ubah". Menurut Subini (2015), pengajaran remedial bertujuan untuk menyembuhkan atau memperbaiki proses pembelajaran yang menjadi penghambat atau dapat menimbulkan masalah. Proses perbaikan dalam penelitian ini dilakukan dengan mengubah cara belajar yang sesuai dengan karakteristik siswa yaitu memlih strategi yang dapat memudahkan siswa dalam memahami konsep sehingga mengurangi miskonsepsi pada siswa yang dibuktikan dengan penurunan miskonsepsi tersebut.

Miskonsepsi pada siswa dalam penelitian ini masih tersisa $12,60 \%$ pada kelas eksperimen dengan kategori rendah, sedangkan pada kelas kontrol sebesar $20,86 \%$ dengan kategori rendah. Hal ini membuktikan bahwa meskipun telah 
diberikan perlakuan melalui pengajaran remedial menggunakan strategi analogi maupun strategi pembelajaran langsung masih terdapat miskonsepsi pada siswa. Hasil penelitian yang dilakukan (Setiawati, Arjaya and Ekayanti, 2014) menunjukkan bahwa miskonsepsi masih menetap (resisten), walaupun siswa kelas IX pada kedua sekolah telah diberikan materi fotosintesis dan respirasi. Menurut Suwarto (2013) Sejumlah miskonsepsi sangat sulit untuk diubah, walaupun telah diusahakan untuk menyangkalnya dengan penalaran yang logis dengan menunjukkan perbedaannya melalui pengamatan sebenarnya, yang diperoleh dari peragaan dan percobaan yang dirancang secara khusus.

Faktor yang mempengaruhi tetap terdapat miskonsepsi pada siswa setelah melakukan penelitian ini yaitu 1) Kemampuan siswa dalam memahami konsep rendah, hal ini dibuktikan dengan hasil belajar siswa untuk mata pelajaran IPA sangat rendah, diperoleh dari nilai ulangan harian. Menurut Yuliati (2017) siswa yang tidak berbakat atau kurang mampu dalam mempelajari IPA, sering mengalami kesulitan dalam proses belajar. 2) Sebagian siswa tidak dapat mengubah pandangan awal meskipun guru telah menjelaskan materi dengan sangat baik, hal ini dibuktikan dengan keterlaksanaan pembelajaran yang mendapatkan nilai sangat baik dengan persentase sebesar $91 \%$ pada kelas kontrol dan sebesar $98 \%$ pada kelas eksperimen. Harrison (2013) menemukan bahwa murid terlihat menerima semua ajaran guru mereka ketika sedang belajar bersama, dan mereka juga berupaya mengikuti setiap arahan pelajaran. Namun, sering pula murid menerima konsep pelajaran yang baru tanpa mengubah pandangan awal. Para penganut konstruktivisme menyatakan bahwa tingkat penerimaan sebuah konsep baru sangat ditentukan oleh kondisi mental seseorang yang dapat diperkaya melalui pengalaman dan keterampilan: apakah diterima, dimodifikasi ataukah ditolak (Harrison, 2013).

\section{Peningkatan Hasil Belajar setelah Pengajaran Remedial mengguna- kan Strategi Analogi}

Hasil penelitian menujukkan bahwa selain terjadi penurunan miskonsepsi, juga terjadi peningkatan hasil belajar pada kelas kontrol maupun kelas eksperimen. Data peningkatan hasil belajar setelah pengajaran remedial menggunakan strategi analogi diperoleh dari nilai gain score. Menurut Meltzer (Herlanti, 2006) pada kelas eksperimen rata-rata nilai gain score sebesar 0,71 dengan kategori tinggi, sedangkan pada kelas kontrol rata-rata nilai gain score sebesar 0,52 dengan kategori sedang. Peningkatan hasil belajar setelah dilakukan pengajaran remedial menggunakan strategi analogi lebih tinggi 0,18 dibandingkan dengan pengajaran remedial menggunakan strategi pembelajaran langsung. Hal ini dikarenakan penggunaan strategi analogi memiliki pemetaan sifat bersama antara konsep baru yang belum dikenal dengankeadaan nyata atau analog. Menurut penganut kontruktivisme para murid harus melihat dan memahami sifatsifat bersama antara analog dan target selama mereka mengembangkan konsep (Harrison, 2013). Dalam penelitian ini siswa menemukan kemiripan yang ditemukan dalam perumpamaan struktur bumi dengan hal yang sudah mereka ketahui yakni buah kiwi, sehingga mereka dapat memahami konsep yang sebelumnya belum mereka ketahui secara nyata/konkrit. Hal ini sesuai dengan pendapat Muadab (Sari, Prasetyo and Utami, 2014) menyatakan bahwa analogi dapat membantu siswa untuk mengerti istilah atau konsep dan mengingatnya dalam waktu yang lebih lama bila dibandingkan dengan pola belajar yang hanya dengan membaca dan menghafal saja. 
Harrison (2013) mengungkapkan bahwa menggunakan analogi untuk belajar sains dapat digambarkan sebagai pengembangan konsep (murid akan berkembang konsep pemikirannya), atau perubahan konsep (membuang konsep tidak ilmiah dalam pikiran) atau keduanya. Pendapat ini terbukti karena siswa dapat memahami materi struktur bumi yang disampaikan menggunakan analogi sehingga hasil belajar siswa dalam penelitian ini menjadi lebih baik, dibuktikan dengan nilai posttest pada kelas eksperimen $87 \%$ siswa yang tuntas.

\section{KESIMPULAN}

Berdasarkan penelitian yang telah dilakukan didapatkan hasil bahwa:

1. Keterlaksanaan pembelajaran kelas eksperimen berupa pengajaran remedial menggunakan strategi analogi sebesar $98 \%$ dengan kategori sangat baik dan keterlaksanaan pembelajaran kelas kontrol berupa pengajaran remedial strategi pembelajaran langsung sebesar $91 \%$ dengan kategori sangat baik.

2. Hasil uji Mann-Whitney sebesar 0,017 yang menunjukkan bahwa terdapat perbedaan miskonsepsi IPA antara pengajaran remedial menggunakan starategi analogi dengan pengajaran remedial menggunakan strategi pembelajaran langsung.

3. Hasil gain score pada kelas eksperimen sebesar 0,71 dengan kategori tinggi, sedangkan pada kelas kontrol sebesar 0,52 dengan kategori sedang. Hal ini menunjukkan bahwa menunjukkan bahwa terdapat peningkatan hasil belajar siswa setelah menggunakan pengajaran remedial menggunakan strategi analogi.

\section{SARAN}

Berdasarkan hasil penelitian di lapangan dan keterbatasan yang ada dalam penelitian maka rekomendasi dalam penelitian ini adalah

1. Bagi penelitian selanjutnya disarankan indikator soal miskonsepsi sebaiknya mengacu pada hasil penelitian sebelumnya

2. Bagi penelitian selanjutnya pengajaran remedial sebaiknya dilakukan dengan menggunakan pendekatan indvidual yang disesuaikan dengan kemampuan masing-masing siswa, supaya siswa mendapat kesempatan untuk mengembangkan kemampuannya masing-masing.

\section{DAFTAR PUSTAKA}

Basri, I. Y. (2011) 'Peningkatan Kompetensi Mahasiswa di bidang CAD/CAM Melalui Penerapan Model Pembelajaran Berbasis Remidial', Jurnal Teknologi Informasi \& Pendidikan, 3(1), pp. 86-101.

Fathurohman, A. (2014) 'Analogi dalam Pengajaran Fisika', Jurnal Inovasi dan Pembelajaran Fisika ISSN : 2355-7109, 1(1), pp. 74-77.

Harrison (2013) Analogi Dalam Kelas Sains. Jakarta: PT. Indeks.

Herlanti (2006) Tanya Jawab Seputar Penelitian Pendidikan Sains. Jakarta: Jurusan Pendidikan IPA Fakultas Tarbias dan Ilmu Keguruan Universitas Islam Negri Syarif Hidayatullah Jakarta.

Kunandar (2014) Penilaian Autentik (Penilaian Hasil Belajar Peserta Didik Bedasarkan Kurikulum 2013). Jakarta: PT. Raja Grafindo Persada.

Prastowo, T. (2011) 'Strategi Pengajaran Sains dengan Analogi: Suatu Metode Alternatif Pengajaran Sains Sekolah', Jurnal Penelitian Fisika dan Aplikasinya (JPFA), 1(1), pp. 8-13.

Praswidiarini, D. and Suyono (2015) 'Penerapan Strategi Analogi yang Diperkuat dengan Praktikum untuk 
Meprevensi Miskonsepsi Siswa pada Konsep Asam dan Basa', UNESA Journal of Chemical Education, 4(3), pp. 532-540.

Sari, E. R., Prasetyo, A. P. and Utami, N. R. (2014) 'Pembelajaran Remidial Menggunakan Analogi pada Materi Mekanisme Transpor Sel', Unnes Journal of Biology Education, 3(2), pp. 147-155.

Setiawati, G. A. D., Arjaya, I. B. A. and Ekayanti, N. W. (2014) 'Identifikasi Miskonsepsi dalam Materi Kelas IX SMP di Kota Denpasar', Jurnal Bakti Saraswati, 3(2), pp. 17-31.

Subini, N. (2015) Mengatasi Kesulitan Belajar Pada Anak. Jogjakarta: PT. Buku Kita.

Suwarto (2013) 'Belajar Tuntas, Miskonsepsi, dan Kesulitan Belajar', JURNAL PENDIDIKAN, 22(1), pp. 85-96.

Yuliati, L. (2017) 'Unit 6 Miskonsepsi Dan Remediasi Pembelajaran IPA'. PJJPGSD Universitas Surabaya, pp. 245-298. Available at: http://pjjpgsd.unesa.ac.id/dok/6.Mo dul-6-Miskonsepsi dan Remediasi Pembelajaran IPA.pdf. 